\title{
Designing the E-Authentic Assessment on Computer Networking Learning in The Revolution Industry 4.0
}

\author{
Ambiyar ${ }^{1 *}$, Waskito ${ }^{2}$, Raimon Efend ${ }^{3}$, Yuyun Irawati ${ }^{4}$ \\ 1,2,4Faculty of Engineering, Universitas Negeri Padang, Padang, Indonesia \\ ${ }^{3}$ Faculty of Computer Science, Universitas Dharmas Indonesia, Dharmasraya, Indonesia \\ e-mail: ambiyar@ft.unp.ac.id ${ }^{1}, \underline{\text { waskito@ft.unp.ac.id² }}, \underline{\text { raimon.efendi@gmail.com }}$, yuyunirawati1440@gmail.com ${ }^{4}$
}

\begin{abstract}
The unavailability of assessment instruments that accordance to the KKNI-based higher education curriculum is also the basis of the research. This study aims at producing an online assessment evaluation model design. The type of this research was Research and Development (R\&D). The research subjects were information system study program students of the Universitas Dharmas Indonesia who took the Computer Networking course. The research data were obtained through validaty and practicality instrument and also observations. Based on the research results, it can be concluded that the online authentic assessment evaluation model that has been designed can be implemented to improve learning competence. Based on descriptions and validations of each material expert, media expert, and learning expert, the results of the validity test show that the authentic assessment developed was valid and feasible to be used.
\end{abstract}

Keywords: Authentic Asessment, Online, $4 C$

\section{Introduction}

The development of technology in the 21 st century has presented its own challenges in all aspects of life, including the aspects of education which are required to be able to create an educational system that can produce quality human resources (BSNP, 2010). The interconnection among technology and science worlds is a prominent feature of the 21 st century, so the synergy between them has become very fast. The fusion of space and time dimensions which have been a determining factor for the success of human mastery on science and technology, effected in the use of information and communication technology in the education world is inevitable (Mukminan, 2014). Various efforts have been made, in order to the development of the educational paradigm in the 21st century is also in line with the graduate competencies' development as well as the quality of the learning process. So, education in the 21st century must pay attention to the use of educational technology, the strategic role of educators and students, learning methods, including the assessment process which is an integral part of the learning process (BSNP, 2010). Referring to the shift in the learning paradigm which states that the increasingly rapid development of information and communication technology is also taking part in learning changes. Technological developments must make it easier to communicate, collaborate and learn (Trilling \& Fadel, 2009). 21st century learning always requires a learning model that is assumed to be relevant for the technology implementation in learning, including the assessment process which is an integral part of the learning process. In other words, the paradigms change and approaches in the technology and information development in the industrial revolution 4.0 era, it must be used as an opportunity for the education world that can make it easier to communicate, collaborate in the learning process (Trilling \& Fadel, 2009).

The increasingly complex challenges in the Industrial revolution 4.0 era require managers and resources involved in the world of education to innovate and be creative in managing the education system (Brown, Kirpal, \& Rauner, 2007). Educational institutions as a medium aimed at developing individual independence according to their competencies (Oji Kennedy, 2011). However, this responsibility is certainly a collective responsibility, where all

\footnotetext{
${ }^{*}$ Corresponding author
}

Received 15 April 2020; Accepted 13 December 2020; Available online 01 March 2021 (c) 2020 JPI. All Rights Reserved 
parties involved in the world of education must take responsibility for the achievement of quality human resources who are professional and competent in their fields. Educational institutions must be able to prepare human resources who have good competence and able to work professionally.

Overcoming the threat of the industrial revolution 4.0 is certainly not easy, an important element that must be of concern to encourage the nation's competitiveness in the era of the industrial revolution 4.0 is to prepare well for more innovative learning management and improve the skills of graduates who have 21 st century skills (Zubaidah, 2018). The development of 21 st century competencies will focus more on specific specializations; the aim of Indonesia's national education must be oriented on efforts to shape the skills and attitudes needed in the $21 \mathrm{st}$ century. Effectiveness in communication, high productivity, increased moral and spiritual values, digital literacy and intensive thinking are the five main aspects of skills in the revolutionary era 4.0 (Osman, Hiong, \& Vebrianto, 2013). Griffin \& Care (2015) classifies 21st century skills and attitudes as ways of thinking (knowledge, critical and creative thinking), ways of learning (literacy and general skills) and ways of learning with others (personal, social and society responsibility), this is also in accordance with the concept of the US-based Partnership for 21st Century Skills (P21) which identifies it as a 4C skill in the 21st century (Partnership for 21st Century Learning, 2015). Thus, the 4C skills must be present in the learning outcome that prepares quality and competitive resources in the era of the industrial revolution 4.0.

Reaching the competence that accordance to the expected learning outcome is one of education peocess objective (Lampinen \& Arnal, 2009). Higher education curriculum implementation based on competence has an impact to students' skill achievement. The student skills acquisition is not only influenced by the learning process, but also by the student assessment process. The evaluation is conducted by the educator is highlighted in the evaluation during the learning process and only the final evaluation (Rosyada, 2007). Therefore, theacer have to preapare the assessment technique before learning process implementation. As a part of process and students learning outcome. Alternative assessment means nontraditional assessment format, it usually needs demonstration construction or students' performance. Alternative assessment format is more purposeful and oriented to students and authentic (Doran, Chan, \& Tamir, 1998). Learning activity implementation is not separated from evaluation activity (evaluation), it is line to one of authentic evaluation principle, that is evalution process has to be a part not be separated from learning process (Majid, 2015). Authentic evaluation is performance evaluation, but not all of performance evaluation is authentic evaluation (Oosterhof, 2014). Learning success is determined by assessment/evaluation. Assessment process includes several proofs that show students learning outcoe achievement. The assessment is conducted integrated with learning activity. So, it is called competence-based assessment. Assessment is conducted by various ways, such as students work collection (portofolio), working (product), homework (problem), performance and written test (paper and pencil) (Razmawaty Mohamed \& Lebar, 2017).

Authentic assessment is part of constructive learning. Several researchers have concluded that educators need to create meaningful learning for students, using information from the real and continuous environment between the knowledge taught and the students experiences (Brown, Collins, \& Duguid, 1989; Council et al., 2001; Council, Education, on Behavioral, \& Practice, 2000). Thus, assessment does not just ask students to repeat the information that they have received. Students also be asked to demonstrate that they have appropriately constructed their knowledge and skills based on the learning process that they undertake. In addition, students must have the opportunity to participate in the construction of meaning. Authentic assessment works not only as an assessment, but also as a medium that can improve their competence.

Assessment is not only as function to identify learning outcome. But, it also can be used to determine the ongoing learning process (Shelia, 2014). Its assumption are follows, when students know what they learn, how they learn it, how the way ti increase their learning, students will build identity as independent learner (Tassinari, 2016). Gulikers states that authentic assessment encourage students to develop skill and competence that relevant to real life (Gulikers, 2006). Authentic assessment also can be used to increase students' skill. In the 
thinking skill traditional assessment that assessed is understanding level and focus on lecturer. Considering to thinking skill traditional assessment that assessed is construction level and application and its focus on students. Other than that, traditional assessment also tends to choose the exist answer. Meanwhile, students' traditional assessment shows or conducts the task or project (Basuki, Ismet, \& Hariyanto, 2014). Authentic assessment is assessment that involves students in the activity that demand students to show their skill as an achievement of knowledge and skill understanding that they have learned (Stiggins \& Chappuis, 2006). Authentic assessment can assess students' skill holistically by assessing the knowledge, attitude and skill. It enables for students to show what they can do (Wulan, 2009). Although, authentic assessment is considered very important, the use is still very limited. It is due to teacher face various difficulties and obstacles either in planning or implementing (Wahyuningsih, Wahyuni, \& Lesmono, 2016). The obstacles are including as teachers' difficulty in preparing assessment tool such as rubric and task.

Considering those problems, several studies have been conducted toward assessment development that integrated with web-based technology. Several studies show the disadvantage of manual evaluation with online evaluation instrument also has many disadvantages, are follows; manual evaluation needs highest timen and cost to produce the completeness of instrument. Evaluation checking process by paper and pencil test is complicater that need much time and tends to be boring (Lemmo \& Mariotti, 2017). Assessment management and process and giving feed back to students are also complicated (Clariana \& Wallace, 2002). Assessment development using computer also have been conducted by several researchers. The study of assessment and evaluation have been conducted a lot by researcher related to online learning evaluation development. Online evaluation system also has been implemented to small group students and it can be accepted well by students as assessment system based on computer (Setemen, 2010).

Other study conducted by Setemen (2014), that is experiment among type using of portfolio assessment and project in computer programming. The results of studi show that portfolio assessment using better than project assessment using in computer programming. The confirmation that portfolio assessment better that project assessment is assessment process of portfolio assessment conducted continuously. Wing-shui (2012), on their study showed that students satisfy with authentic assessment and feedback strategy in computer programming learning. On other hand, their competence also develops more better when compared to conventional method using. Study that related to authentic assessment conducted by Wing-Shui about the effect of authentic assessment and feedback strategy on computer programming subject (Wing-shui, 2012).

Online assessment E-authentic model is designed to be implemented for students. So, it can streamline the assessment by lecturer and be able to increase learning competence. Webbased authentic assessment is very potential. But, in applying it, there are several concern such as increasing the plagiarism risk and verify students' indentity as user. Another obstacle, that must be faced are follows; lak of time or training in implementing. But, practical problem of the sort can be handled with potential utilizing that had by web-based authentic assessment. The design of web-based assessment will be designed in user friendly and be able to conduct the assessment on students' $4 \mathrm{C}$ skill effectively and efficiently. It is $21^{\text {st }}$ century skill that essential for students' real life.

\section{Method}

This study is preliminary of development research that using Research and Development (R\&D) design to produce certain product, and test the the product effectiveness (Sugiyono, 2014). This research development was designed to produce authentic assessment instrument in computer networking learning to assess students' skill of Information System Study Program, Faculty of Computer Science, Universitas Dharmas Indonesia. Need analysis was a stage that aims at describing the present condition and students' and teachers need in computer networking learning. So, in this stage, they can describe the gap among present condition and students' priority need that related to students' competence in in the $21^{\text {st }}$ century and learning assessment process are expected in computer networking at higher education. Data collecting 
technique was implemented by distributing the valid and reliable questionnaire. The samples of this need analysis study were 50 students of Information System Program Study, Faculty of Computer Science UNDHARI who took Computer Networking course.

The development model used was ADDIE model that consists of five stages, are follows; 1) Analysis, 2) Design, 3) Development, 4) Implementation, dan 5) Evaluation. The process conducted in this study just got the development stage, that is producing the instrument design and supporting media that have been validated by experts. Procedural fase of authentic assessment development in Computer Networking learning used ADDIE model. This study discussed about evaluation model design of online Authentic Asessment online (E-Authentic Asessement). In this design stage, several stages conducted were follows; need analysis. In this stage, researcher spreads the questionnaire to the lecturers and students. Then, researcher writes the support literature review. Next, in this stage, researcher conducted the Focus Discission Droup (FGD) that aims at collectiong experts' suggestion related to developmet of online assessment evaluation model. So, it is expected that the results of this stage can produce a valid online assessment evaluation model.

After the analysis stage finished, next stage is designing e-authentic assessment product. Website-based uuthentic assessment product used based on PHP and MySQI database. E-authentic assessment design uses several reference sources as guideline to develop the content. The next stage is collectiong the evaluation material, questions, portfolio, questions of concept understanding and the answer of questions that will be entered to eauthentic evaluation with referring to skill achievement inicatir that had been determined. After reference material, video, question and answer for collecting question, the next stage is designing product. Several designing stage of e-authentic assessment products, are follows; assessment authentic instrument design. In this assessment instrumen designing stage, conducting the interview with lecturer and observation related to assessment material that will be assessed, designing the web interface and database. The next stage is validation through Focus Group Discussion (FGD). Researcher analyzes judgement expert result uses Aiken's V validity coefficient, it can bee seen on Formula 1. In order to calculate the Content Validity Coefficient that based on experts' panel assessment, as much as $\mathrm{n}$ people to an item regarding the extent to which the item represents the constructured being measured, Aiken has formulated Aiken's $\mathrm{V}$ formula. The assessment is conducted by giving number among 1 (very unrepresentative or highly irrelevant) to 5 (very presentative or highly relevant (Azwar, 2015).

Based on the Aiken's $V$ formula, obtained the description that $n$ is Total of Evaluator Panel (expert), lo is The Number of Lowest Validity Assessment (in this case $=1$ ), $c$ is The Number of Highest Validity Assessment (in this case $=5$ ), $r$ is The Number Given by Evaluator, where $s ; r-l o$. Due to $V$ number range that can be obtained among 0 until 1,00 . So, the number of 0,667 can be interpreted as sufficiently high coefficient for the item.

\section{Results and Discussions Need Analysis}

On the analysis stage has been conducted the need assessment. Need assessment is literature review activity that related to authentic assessment and survey to lecturers on faculty of computer science Universitas Dharmas Indonesia. Literature review was conducted with the aim at comparing several related research results conducted by researchers of computers and education which came from several scientific articles. This literature study is important to see the position of the research to be conducted.

After reviewing several articles, the researchs that related to development of the exist computer-based assessment application was specially used on the Computer Networking learning. It means that the developed application will be implemented on the other learning material. So, the application has to modify. Other than that, the developed application has not been provided yet the features for sharing assessment rubric. Assessment rubric has to include three aspects, as follows kognitive, affective and psychomotor.

The second activity analysis stage (need assessment) was survey to lecturer in Faculty of Computer Science Universitas Dharmas Indonesia. The total respondent in this survey was 
5 lecturers. Survey was conducted by spreading the questionnaire that related to the exist learning condition and the expecting related to students' assessment.

The assessment results of need analysis instrument regard an overview of the current condition and overview of learning process priority/need of Computer Networking course. Based on the data analysis result on the need analysis stage state that lecturer need analysis to increase computer networking learning quality shows that the lecturers have high expectation regard learning process. Teachers' expectation of learning process has to increase the $21^{\text {st }}$ century learning skills (critical thinking, communication, collaboration, creativity). The description among the current situation and students' priority/need was 2,53 that be able to assume that lecturers need innovative learning assessment model to explore students' skills in learning process.

Students' need analysis of computer networking learning process are hoping a lot in computer networking learning process. Students' expectation of $21^{\text {st }}$ century skills (critical thinking, communication, collaboration, creativity) are in the high category with ana average 4,6, it means that students need to develop more effective and efficient learning assessment model in developing their academic. Based on need analysis, evaluation model development based on authentic evaluation that support learning process had been done. Generally, the results of need analysis that had been done can be illustrated on Figure 1.

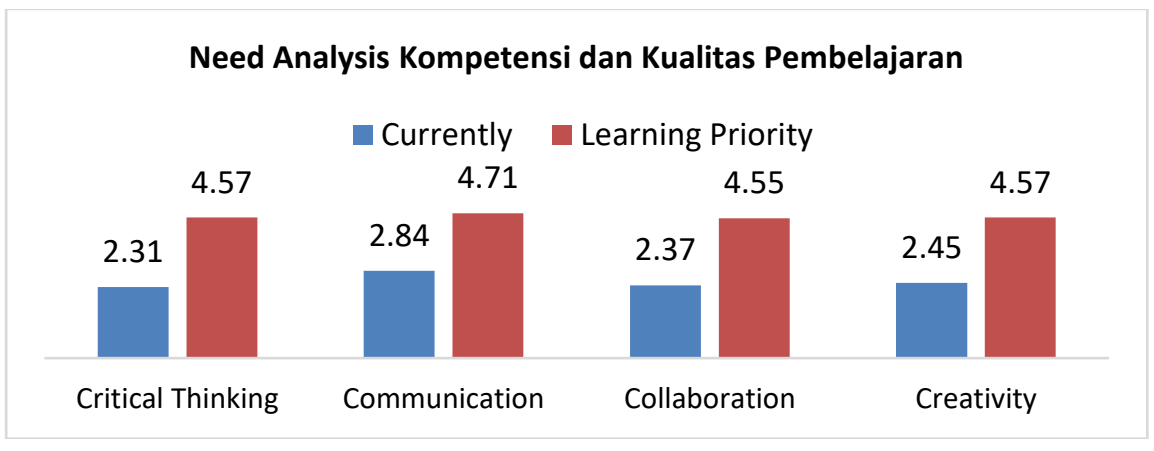

Figure 1. Need Analysis Result

\section{Assessment Authentic Rubric Design}

Design stage becoming stage that have to be passed after conducting analysis stage (need assessment), also giving several research results. Authentic assessment consists of tasks and rubrics, rubrics are scoring tool that which contains a list of criteria for a work or task. Shortly, scoring rubrics consists of several components, are follows; dimention, definition, example, scale and standars. Dimention will be basis to measure students' performance. Definition and example are description of each dimention. A scale is defined because it will be used to judge the dimensions, whereas a standard is defined for each performance category. Even though the rubric or scoring rubrics have been compiled as closely as possible, it must be realized that it is impossible for the rubric that has been compiled to be perfect or the only criterion for assessing student performance in certain areas. Table 1 is one of the rubric designs that conducted to assess the student discussion process in completing assignments. As a basis for compiling a rubric, scoring guidelines are also made in the assessment of presentations.

Tabel 1. Rubric Design of Dicussion Assessment

\begin{tabular}{|c|c|c|}
\hline \multicolumn{3}{|c|}{ Rubric Discussion Assessment (Individual) } \\
\hline Students' name & : $\ldots \ldots \ldots \ldots \ldots \ldots \ldots \ldots$ & \\
\hline Student ID Number & : ............... & \\
\hline Discussion Topic & . & \\
\hline Week & 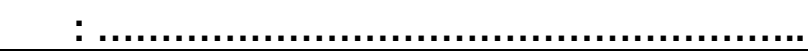 & \\
\hline \multirow{2}{*}{ No. } & \multirow{2}{*}{ Assessment Criterias (4c) } & Score \\
\hline & & $\begin{array}{lllll}1 & 2 & 3 & 4 & 5\end{array}$ \\
\hline
\end{tabular}




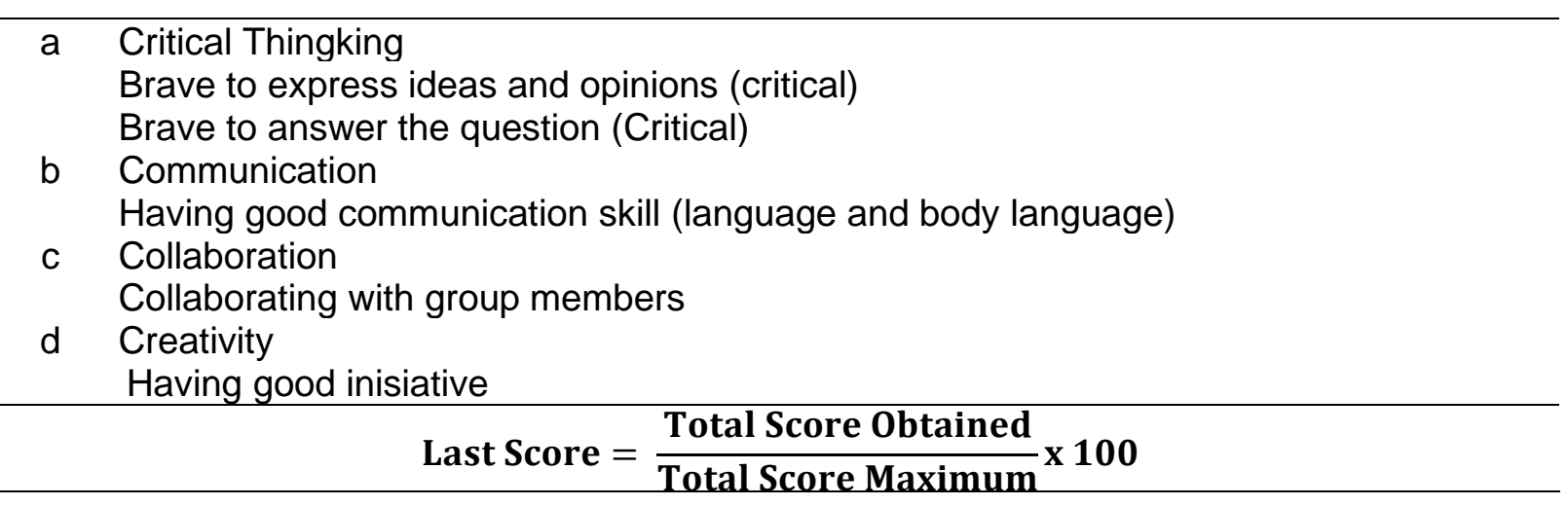

\section{E-Authentic Assessment Web Design}

After conducting a literature review and needs analysis related to authentic assessment features, the next step is designing a prototype. The excellent feature in this E-Authentic Assessment prototype is that lecturers can independently create taught courses, lecturers can create managed classes, lecturers can create assessment groups, lecturers can create or select rubrics to be used in the assessment, and lecturers can make or start an assessment.

An overview of the system design depicted in the use case diagrams and several system interface views as an implementation result of the model in the use case diagram as shown in Figure 2, is a series of activities and are interrelated which form a system regularly that conducted by 2 actors, namely lecturer actors and students. Several series of activities conducted by lecturer include registering which is only done once at the beginning of entering the system, then using a user account that has been created by the lecturer and students, they can log in, the next activity is validating the class participants, creating courses, dividing groups, making rubrics, giving tests, conducting assessments, and managing the assessment results. Meanwhile, the things that student actors can do after successfully logging in are doing assignments, taking exams and a series of assessments.

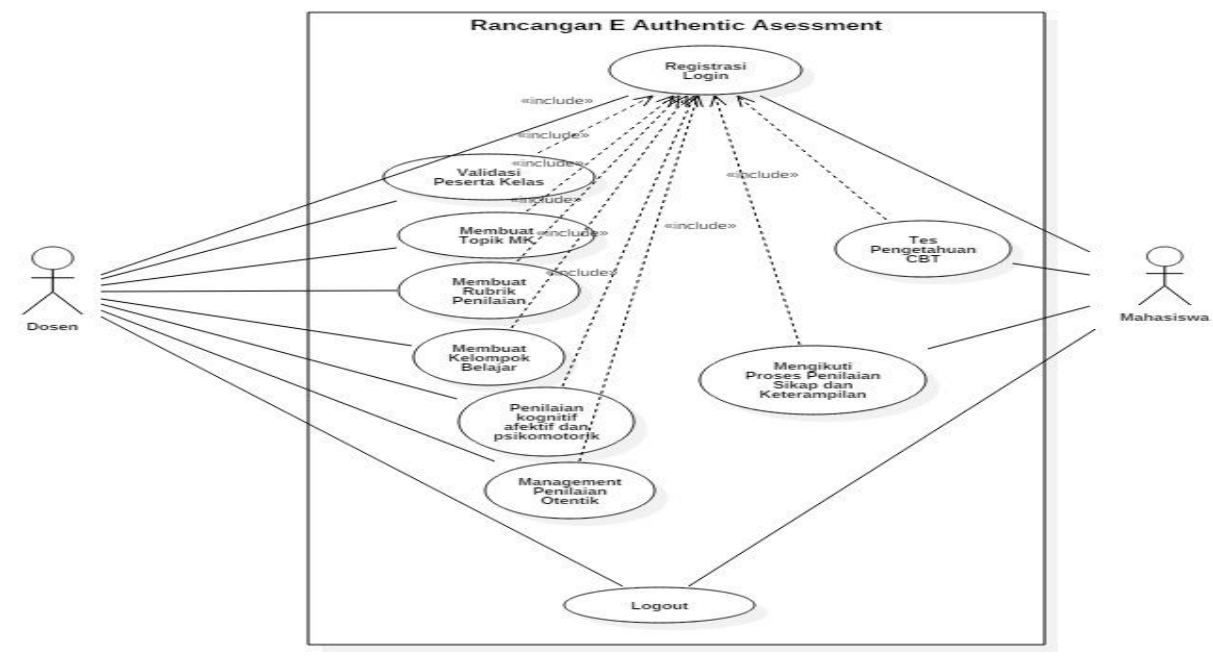

Figure 2 Use case diagram of E-Authentic asessment

The web-based authentic assessment design is conducting using a data flow diagram that will explain the information procedures on the system. The data flow diagram can clearly describe all activities. Context diagram of the e-authentic assessment design which describes the general processes that occur in the assessment process in the information systems study program. In this context diagram involves three external entities, namely admin, lecturers, and students. 


\section{Interface Design}

The next step is the input-output design, which consists of a form that functions like an e-authentic assessment system user interface. The design in the input output accepts input from the application user and the system will provide the results in a report or output display. The interface design contained in the student learning outcomes evaluation application includes the login page design, administration page, student list, subject and topic list, evaluation design and evaluation criteria.

The rubric page design is a display that contains information on ranking topics. On this page, you can add criteria data, view and verify criteria data. The filling instructions on the criteria section of the criteria page, which contains information about the criteria for the evaluation section. The page for designing criteria for the rubric can be seen in Figure 3.

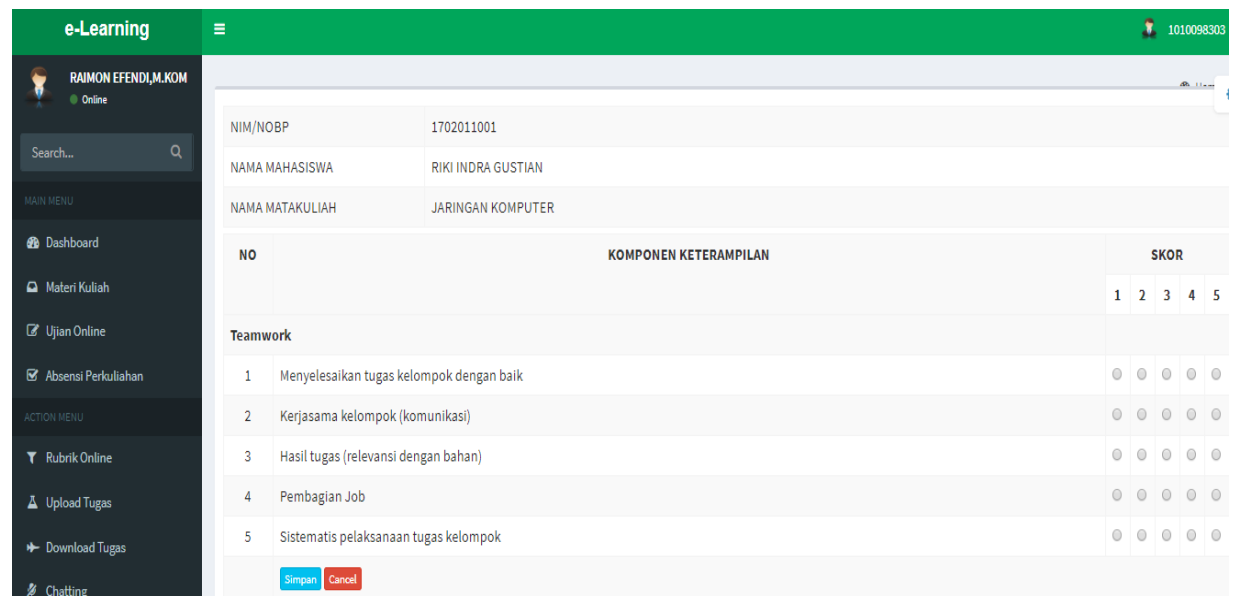

Figure 3 Initial Design of Assessment Rubric

\section{Validation Design}

Validation data were obtained from five experts consisting of language, learning media and material experts. Experts assess research products consisting of RPS and SAP on computer networking course, and web-based authentic assessment media. Validators are asked to provide assessments and suggestions for improving learning evaluation models and learning tools that have been designed. Validation of the Semester Learning Plan (RPS) and Lesson Plan (SAP) on the computer networking course is assessed from the aspects of the RPS component, SAP component, language and evaluation system. Overall, the results of the RPS and SAP Computer Networking validation can be seen in Table 2.

Table 2. The Results of RPS and SAP Validation

\begin{tabular}{clcc}
\hline No & \multicolumn{1}{c}{ Aspects } & Average & Category \\
\hline 1 & RPS Component & 0,85 & valid \\
2 & SAP Component & 0,92 & valid \\
3 & Language & 0,86 & valid \\
4 & Evaluation System & 0,83 & valid \\
\hline & Average & $\mathbf{0 , 8 7}$ & Valid \\
\hline
\end{tabular}

Based on the expert's assessment, the RPS and SAP validation obtained a value of 0.87. Referring to Azwar (2014) that if the range of numbers $V$ obtained $=0.667$ can be interpreted as a high enough coefficient. So, it can be categorized that the validity is in the "valid" category. Validation of website-based authentic assessment media on computer networking courses is assessed from the aspects of website components, appearance, multimedia, and language. The results of media validation from the website components aspect can be seen in table 3. 
Table 3. The Results of E-Authentic Assessment Media Validation

\begin{tabular}{lcc}
\hline \multicolumn{1}{c}{ Aspects } & Value & Category \\
\hline Website content according to RPS & 0,86 & valid \\
Website instructions assist in accessing the assessment & 0,87 & valid \\
Website pages are adequate for presenting information & 0,92 & valid \\
This learning weebsite assessment material is systematic & 0,84 & valid \\
The assessment on the learning website is easily accessible & 0,87 & valid \\
Learning website assessment is logically connected & 0,84 & valid \\
The website applies the principles of motivation and readability & 0,86 & valid \\
Website helps students perceive learning messages & 0,89 & valid \\
Assessment on the Website encourages creative and critical students & 0,87 & valid \\
Learning messages on the Website help increase student cognitive & 0,92 & valid \\
engagement & & \\
Website messages help students learn concepts (cognitive) & 0,85 & valid \\
The website teaches students to solve problems & 0,92 & valid \\
Website navigation helps users find out the website content & 0,87 & valid \\
The message on the website contains an element of attitude change & 0,89 & valid \\
Website navigation helps users find out the website content & 0,85 & valid \\
The website provides facilities for conducting feedback & 0,88 & valid \\
\hline
\end{tabular}

Overall, the validated aspects of this website media consist of website component aspects, appearance aspects, multimedia aspects and language aspects. Based on the experts' assessment who are experts in their field, media validation of authentic website-based assessment media gets a value of 0.87 . If the range of number $V$ obtained is $\geq 0.667$ it can be interpreted as a high enough coefficient, so that it can be categorized that the validity is in the "valid" category.

\section{Revision Design}

After the product design is validated through the material experts, media experts, learning experts and linguists assessment, the researcher revises the product design that developed based on expert input. However, there are a several suggestions to improve the online authentic assessment media, namely the need to add material, so it becomes a learning reference for students. Table 4 is a recap of suggestions and revisions which are used as material for revising the E-Authentic Assessment model.

Table 4. The Resume of Validator Recommendation to Product

\begin{tabular}{lll}
\hline No & \multicolumn{1}{c}{ Experts } & \multicolumn{1}{c}{ Validator Recommendation } \\
\hline 1 & Material Expert & 1. $\begin{array}{l}\text { Several main material of computer networking must be } \\
\text { added and sync with the curriculum and also learning } \\
\text { objective indicator }\end{array}$ \\
& $\begin{array}{l}\text { 2. } \begin{array}{l}\text { On the figure and table material must add references. } \\
\text { 3. Writing scientific names that are not in accordance with the } \\
\text { correct writing system }\end{array} \\
\end{array}$ & 1. $\begin{array}{l}\text { The content in the menu still must be perfected that } \\
\text { characterized the } 21^{\text {st }} \text { century skill assessment }\end{array}$ \\
& 2. $\begin{array}{l}\text { Contents (Text and images) that do not manifest with the } \\
\text { topic of Computer Networking are reduced }\end{array}$ \\
& 1. Language use must be detailed but easy to understand \\
\hline
\end{tabular}

The responses of lecturers and students are also very necessary in developing webbased authentic assessment, it is conducted because the assessment support later will be used in teaching and learning by lecturers and students. Indeed, web-based authentic assessment 
has a significant role involving lecturers and students. Students play an active role in determining the value to be achieved, while lecturers provide feedback on student performance. In addition, by designing authentic assessment using web-based media, the time needed is more efficient, because lecturers can provide assessments as soon as students finish their working.

The results of the lecturers' responses to the web-based authentic assessment obtained a percentage of $85.00 \%$ with very good criteria. it means that the assessment of web media that has been developed is feasible and suitable to use as a means of learning and assessment in the class. It is evidenced by the students' grades that have improved in the past and the efficiency of teacher time in assessments.

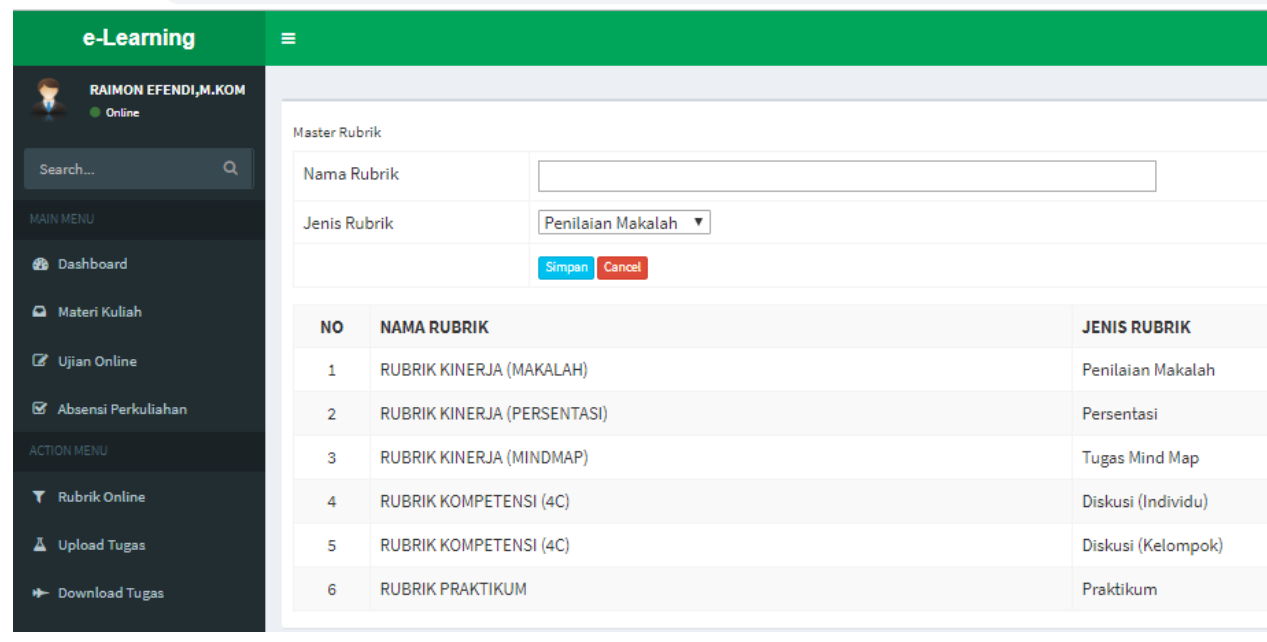

Figure 4. E-Authentic Assessment Display

Figure 4 is an authentic web evaluation interface display after a revision is made regarding the suggestion that given by the experts. On this page, the lecturer can view and manage the rubric that will be used to conduct the assessment. This rubric consists of performance rubric assessment, practicum assessment rubric, competency rubric 4c which will assess students from the categories of communication, creativity, collaboration skills and critical thinking skills. The rubric is a type of quantitative rubric; this rubric contains the scores for each sub-component in the rubric. To be able to see the assessment results of each group, you can select the type of rubric that used by each test.

In the design phase, a web-based e-authentic assessment model has been designed. Furthermore, the model that has been developed is implemented in the prototype of web-based assessment system. The excellent feature of this web-based e-authentic assessment is that the lecturer can create or select a rubric to be used in the assessment, and the teacher can make or modify the assessment as needed. In general, the system prototype that has been produced has met the elements of how to conduct an online authentic assessment. To see whether this system has worked optimally, it is necessary to conduct limited trials as well as wider trials of experimental research in the real class.

\section{Discussions}

Assessment is not only as function to identify learning outcome. But, it also can be used to determine the ongoing learning process (Shelia, 2014). Its assumption are follows, when students know what they learn, how they learn it, how the way ti increase their learning, students will build identity as independent learner (Tassinari, 2016). Gulikers states that authentic assessment encourage students to develop skill and competence that relevant to real life (Gulikers, 2006). Authentic assessment also can be used to increase students' skill. In the thinking skill traditional assessment that assessed is understanding level and focus on lecturer. Considering to thinking skill traditional assessment that assessed is construction level and application and its focus on students. Other than that, traditional assessment also tends to 
choose the exist answer. Meanwhile, students' traditional assessment shows or conducts the task or project (Basuki, Ismet, \& Hariyanto, 2014).

Authentic assessment is assessment that involves students in the activity that demand students to show their skill as an achievement of knowledge and skill understanding that they have learned (Stiggins \& Chappuis, 2006). Authentic assessment can assess students' skill holistically by assessing the knowledge, attitude and skill. It enables for students to show what they can do (Wulan, 2009). Although, authentic assessment is considered very important, the use is still very limited. It is due to teacher face various difficulties and obstacles either in planning or implementing (Wahyuningsih, Wahyuni, \& Lesmono, 2016). The obstacles are including as teachers' difficulty in preparing assessment tool such as rubric and task.

Considering those problems, several studies have been conducted toward assessment development that integrated with web-based technology. Several studies show the disadvantage of manual evaluation with online evaluation instrument also has many disadvantages, are follows; manual evaluation needs highest timen and cost to produce the completeness of instrument. Evaluation checking process by paper and pencil test is complicater that need much time and tends to be boring (Lemmo \& Mariotti, 2017). Assessment management and process and giving feed back to students are also complicated (Clariana \& Wallace, 2002). Assessment development using computer also have been conducted by several researchers. The study of assessment and evaluation have been conducted a lot by researcher related to online learning evaluation development. Online evaluation system also has been implemented to small group students and it can be accepted well by students as assessment system based on computer (Setemen, 2010).

Other study conducted by Setemen (2014), that is experiment among type using of portfolio assessment and project in computer programming. The results of studi show that portfolio assessment using better than project assessment using in computer programming. The confirmation that portfolio assessment better that project assessment is assessment process of portfolio assessment conducted continuously. Wing-shui (2012), on their study showed that students satisfy with authentic assessment and feedback strategy in computer programming learning. On other hand, their competence also develops better when compared to conventional method using. Study that related to authentic assessment conducted by Wing-Shui about the effect of authentic assessment and feedback strategy on computer programming subject (Wingshui, 2012).

Online assessment E-authentic model is designed to be implemented for students. So, it can streamline the assessment by lecturer and be able to increase learning competence. Webbased authentic assessment is very potential. But, in applying it, there are several concern such as increasing the plagiarism risk and verify students' indentity as user. Another obstacle, that must be faced are follows; lak of time or training in implementing. But, practical problem of the sort can be handled with potential utilizing that had by web-based authentic assessment. The design of web-based assessment will be designed in user friendly and be able to conduct the assessment on students' $4 \mathrm{C}$ skill effectively and efficiently. It is $21^{\text {st }}$ century skill that essential for students' real life.

\section{Conclusion and Suggestions}

This study aims to describing the results of need analysis in web-based authentic assessment development process (e-authentic assessment) of computer networking course. Based on need analysis that have been conducted obtained the understanding of lecturer priority/need in the learning assessment process of computer networking can be seen that lecturers have highest expectation toward learning assessment process that integrated with technology, when their expectation toward learning assessment process that be able to increase $21^{\text {st }}$ century skills (critical thinking, communication, collaboration, creativity). Based on the results and discussions of this research, shows that e-authentic assessment development is needed. e-authentic assessment evaluation design that have been stated worthy by experts, must be assessed in biggest scale, so it can be used to support learning process for Faculty of Computer Science students at Universitas Dharmas Indonesia. Evaluation model development 
have been developed in the future to be uploaded from Play Store or Google Play. So, a lot of people can use this application easier by downloading.

\section{References}

Azwar, S. (2015). Reliabilitas dan Validitas. Pustaka Belajar.

Basuki, Ismet, \& Hariyanto. (2014). Asesmen Pembelajaran. PT. Remaja Rosdakarya.

Brown, A., Kirpal, S. R., \& Rauner, F. (2007). Identities at Work. Springer Netherlands.

Brown, J. S., Collins, A., \& Duguid, P. (1989). Situated cognition and the culture of learning. Educational researcher, 18(1), 32-42. https://doi.org/10.3102/0013189X018001032.

BSNP. (2010). Paradigma Pendidikan Nasional di Abad-21. Badan Standart Nasional Pendidikan.

Clariana, R., \& Wallace, P. (2002). Paper-based versus computer-based assessment: Key factors associated with the test mode effect. British Journal of Educational Technology, 33(5), 593-602. https://doi.org/10.1111/1467-8535.00294.

Council, N. R., Education, D. B. S. S., Education, C., Assessment, B. T., Assessment, C. F., Glaser, R., ... Pellegrino, J. W. (2001). Knowing What Students Know: The Science and Design of Educational Assessment. National Academies Press.

Council, N. R., Education, D. B. S. S., on Behavioral, C. S. S., \& Practice, C. D. S. L. C. L. R. E. (2000). How People Learn: Brain, Mind, Experience, and School: Expanded Edition. National Academies Press.

Doran, R. L., Chan, F., \& Tamir, P. (1998). Science Educator's Guide to Assessment. National Science Teachers Association.

Eko Risdianto. (2019). Analisis Pendidikan Indonesia di Era Revolusi Industri 4.0.

Griffin, P., \& Care, E. (2015). Assessment and Teaching of 21st Century Skills. Switzerland: Springer.

Gulikers. (2006). Authenticity is in the Eye of the Beholder. OpenUniversiteitNedherland, (Authentic Assessmen), 160.

Lampinen, J. M., \& Arnal, J. D. (2009). A Revision of Bloom's Taxonomy: An Overview. $\begin{array}{llll}\text { American Journal of Psychology, } & \text { 122(1), }\end{array}$ https://doi.org/10.1207/s15430421tip4104.

Lemmo, A., \& Mariotti, M. A. (2017). From paper and pencil- to Computer-based assessment : several issues raising in the comparison. Cerme 10, (1993).

Majid, A. (2015). Penilaian Autentik Proses dan Hasil Belajar. PT. Remaja Rosdakarya.

Mukminan. (2014). Tantangan Pendidikan di Abad 21. Seminar Nasional Teknologi Pendidikan 2014. Universitas Negeri Surabaya.

Oji Kennedy, O. (2011). Philosophical and Sociological Overview of Vocational and Technical Education in Nigeria. International Journal of Academic Research in Business and Social Sciences, 01. https://core.ac.uk/download/pdf/25801184.pdf.

Oosterhof, A. (2014). Developing and Using Classroom Assessments. Pearson Education.

Osman, K., Hiong, L. C., \& Vebrianto, R. (2013). 21st Century Biology: An Interdisciplinary Approach of Biology, Technology, Engineering and Mathematics Education. Procedia Social and Behavioral Sciences, 102(Ifee 2012), 188-194. https://doi.org/10.1016/j.sbspro.2013.10.732.

Partnership for 21st Century Learning. (2015). P21 Framework Definition. Retrieved September 15, 2018, from http://www.p21.org/our-work/p21framework/P21_Framework_Definitions_New_Logo2015.pdf\%0A. 
Razmawaty Mohamed, \& Lebar, O. (2017). Authentic Assessment in Assessing Higher Order Thinking Skills. 7(2), 466-476. https://doi.org/10.6007/IJARBSS/v7-i2/2021.

Rhenald Kasali. (2018). Disruption (9th ed.). Gramedia.

Rosyada, D. (2007). Paradigma Pendidikan Demokratis. Kencana Prenada Media Group.

Setemen, K. (2010). Pengembangan evaluasi pembelajaran online. Jurnal Pendidikan Dan Pengajaran, $43(3)$, https://ejournal.undiksha.ac.id/index.php/JPP/article/viewFile/124/118.

Setemen, K. (2014). Pengaruh Jenis Asesmen Terhadap Hasil Belajar Pemrograman Komputer. Prosiding Seminar Nasional Forum Pimpinan Pascasarjana LPTK Indonesia.

Shelia, T. Y. (2014). Transforming pedagogies: Integrating 21st century skills and Web 2.0 technology. Turkish Online Journal of Distance Education, 12(1), 166-173. https://doi.org/10.17718/tojde.32300.

Stiggins, R., \& Chappuis, J. (2006). What a Difference a Word Makes: Assessment "for" Learning Rather than Assessment "of" Learning Helps Students Succeed. Journal of Staff Development, 27.

Sugiyono. (2014). Metode Penelitian Kuantitatif Kualitatif dan R\&D. Alfabeta.

Tassinari, M. G. (2016). Assessment for learning - assessment for becoming. (July).

Trilling, B., \& Fadel, C. (2009). 21st Century Skills: Learning for Life in Our Times. Wiley.

Wahyuningsih, R., Wahyuni, S., \& Lesmono, A. D. (2016). Pengembangan Instrumen Self Assessment Berbasis Web. Jurnal Pembelajaran Fisika, 3(1), 338-343. http://jurnal.unej.ac.id/index.php/JPF/article/view/3087.

Wing-shui. (2012). The Impact of Peer Assessment and Feedback Strategy in Learning Computer Programming in Higher Education. Issues in Informing Science and Information Technology, 9.

Wulan, A. R. (2009). Kemampuan Calon Guru Biologi Dalam Menyusun Rubrik Analitis Pada Asesmen Kinerja. XIV(1), 45-48. https://doi.org/10.21831/jpms.v14i1.172.

Zubaidah, S. (2018). Mengenal 4C: Learning and Innovation Skills untuk Menghadapi Era Revolusi Industri 4.0. 2nd Science Education National Conference, (April), 1-18. Retrieved

from https://www.researchgate.net/publication/332469989_Mengenal_4c_Learning_And_Inn ovation_Skills_Untuk_Menghadapi_Era_Revolusi_Industri_40_1. 